\title{
BMJ Open Impact of electronic cigarette ever use on lung function in adults aged 45-85: a cross-sectional analysis from the Canadian Longitudinal Study on Aging
}

\author{
Divya Joshi (1) , ${ }^{1}$ MyLinh Duong, ${ }^{2}$ Susan Kirkland, ${ }^{3}$ Parminder Raina ${ }^{1}$
}

To cite: Joshi D, Duong ML, Kirkland S, et al. Impact of electronic cigarette ever use on lung function in adults aged 4585: a cross-sectional analysis from the Canadian Longitudinal Study on Aging. BMJ Open 2021;11:e051519. doi:10.1136/ bmjopen-2021-051519

- Prepublication history and additional supplemental material for this paper are available online. To view these files, please visit the journal online (http://dx.doi.org/10.1136/ bmjopen-2021-051519).

Received 22 March 2021 Accepted 11 October 2021

\section{Check for updates}

(c) Author(s) (or their employer(s)) 2021. Re-use permitted under CC BY-NC. No commercial re-use. See rights and permissions. Published by BMJ.

${ }^{1}$ Department of Health Research Methods, Evidence, and Impact, McMaster University, Hamilton, Ontario, Canada

${ }^{2}$ Division of Respirology, McMaster University, Hamilton, Ontario, Canada

${ }^{3}$ Department of Community Health and Epidemiology, Dalhousie University, Halifax, Nova Scotia, Canada

Correspondence to Dr Parminder Raina; praina@mcmaster.ca

\section{ABSTRACT}

Objective To describe the sociodemographic characteristics associated with e-cigarette ever use and to examine the impact of e-cigarette ever use on lung function impairment in an ageing population.

Design A cross-sectional analysis of data from the Canadian Longitudinal Study on Aging.

Setting A national stratified sample of 44817 adults living in Canadian provinces.

Participants Respondents included participants aged 4585 and residing in the community in Canadian provinces. Outcome measures The Global Lung Function Initiative normative values for forced expiratory volume in the first second $\left(\mathrm{FEV}_{1}\right)$, forced vital capacity (FVC), forced expiratory ratio ( $\mathrm{FEV}_{1} / \mathrm{FVC}$ ) appropriate for age, sex, height and ethnicity were used to interpret the severity of lung function impairment. Multinomial logistic regression analysis was used to examine the impact of e-cigarette ever use on obstructive and restrictive lung function impairment.

Results The prevalence of e-cigarette ever use was $6.5 \%$ and varied by sociodemographic factors including higher prevalence among individuals younger than 65 years, those with lower education attainment and those with lower annual household income. E-cigarette ever use was associated with 2.10 (95\% Cl 1.57 to 2.08) times higher odds of obstructive lung function impairment after adjusting for conventional cigarette smoking and other covariates. Individuals with exposure to e-cigarette ever use and 15 or more pack-years had 7.43 (95\% Cl 5.30 to 10.38) times higher odds for obstructive lung function impairment when compared with non-smokers and non-ecigarette users after adjusting for covariates. Smokers with 15 or more pack-years had higher odds of restrictive lung function impairment irrespective of e-cigarette ever use. Conclusions Ever use of e-cigarettes was found to be associated with obstructive lung function impairment after adjusting for covariates, suggesting that e-cigarette use may be adding to the respiratory and other chronic disease burden in the population.

\section{INTRODUCTION}

Chronic respiratory diseases are among the leading causes of morbidity and mortality and contribute substantially to the burden of non-communicable diseases globally. ${ }^{1}$

\section{Strengths and limitations of this study}

- The study included a large, nationally generalisable sample to report the prevalence of e-cigarette ever use and examine its association with lung function impairment among older adults.

- The Global Lung Function Initiative normative values for forced expiratory volume in the first second, forced vital capacity and forced expiratory ratio appropriate for age, sex, height and ethnicity were used to reliably interpret the severity of lung function impairment.

- A major limitation is that information on the frequency, intensity and duration of e-cigarette use was unavailable and not assessed.

- Temporality of association between e-cigarette ever use and lung function impairment cannot be established due to the cross-sectional nature of the data.

Smoking is the most prevalent risk factor for chronic respiratory diseases, and similar to conventional cigarettes, evidence shows that electronic cigarette (e-cigarette) use also exposes users to nicotine, tobacco-specific nitrosamines, aldehydes, volatile organic compounds, metals and other toxicants. ${ }^{2}$ In Canada, although e-cigarettes containing nicotine are widely available, they were illegal until May 2018. ${ }^{3}$ A population-based survey conducted in 2013 estimated $8.5 \%$ of all Canadians aged 15 years and older and 3.7\% of those aged 45 years and older have ever used an e-cigarette. ${ }^{4}$ By 2017 , this prevalence had increased to $15 \%$ of all Canadians aged 15 years and older, ${ }^{5}$ indicating a rapid growth in ever use of e-cigarettes. Although there is substantial research examining adoption of e-cigarettes in youth, not much has been documented regarding sociodemographic factors associated with e-cigarette ever use in the older adult population, particularly in those 65 years and older.

In addition, despite the evidence from animal models, research examining the 
effects of e-cigarette use on pulmonary damage in humans, especially among middle and older aged adults is sparse. Research from in vitro and animal studies reported an association between use of nicotine-containing e-cigarettes and increased airway hyper-reactivity, cytokine expression and lung tissue destruction, which are effects associated with the development of chronic obstructive pulmonary disease (COPD) ${ }^{6}$ Animal models also showed that e-cigarette use without nicotine has the potential to cause lung damage. ${ }^{7}$ Among the limited number of studies that have examined this association in humans, the results suggest that e-cigarette ever and current use is associated with increased risk of respiratory symptoms and chronic pulmonary disorder, a decline in forced expiratory volume in the first second $\left(\mathrm{FEV}_{1}\right)$, forced expiratory ratio $\left(\mathrm{FEV}_{1} /\right.$ forced vital capacity $\left.(\mathrm{FVC})\right)$ and forced expiratory flow in current or former conventional cigarette smokers and never smokers. ${ }^{8-13}$ However, other studies have failed to find such associations. ${ }^{14}{ }^{15}$ Further, the rise in e-cigarette ever use may partly be attributed to the promotion of e-cigarettes as a safer alternative to conventional cigarettes, ${ }^{16-20}$ with almost one-third of current or former cigarette smokers in Canada reporting using it as a smoking cessation tool. ${ }^{3}$ However, evidence suggests that e-cigarettes may only be moderately effective at helping smokers quit smoking, and most e-cigarette users may continue to use both e-cigarettes and conventional cigarettes (dual use). It is also not clear whether e-cigarette ever use among conventional cigarette smokers confers additional risk to a population that is already at a high risk for adverse health outcomes. Some studies have shown dual use of e-cigarettes and convention cigarettes to be associated with higher risk of cardiovascular disease and COPD compared with convention cigarette use only, ${ }^{21}{ }^{22}$ whereas other studies have shown e-cigarette use to reduce exacerbations and improve symptoms in smokers with COPD. ${ }^{23} 24$

Overall, population-based research studies examining the sociodemographic characteristics associated with e-cigarette ever use and the potential impact of e-cigarette ever use on respiratory health in older adults is currently lacking. The purpose of this study is to estimate the prevalence of e-cigarette ever use in the middle and older age population (45-85 years) and identify characteristics of ever e-cigarette users. Additionally, we also examine the impact of e-cigarette ever use, including the dual impact of e-cigarette and conventional cigarette use on lung function impairment in middle to older aged adults. Identification of high-risk subgroups in the population and examining the impact of e-cigarette use on lung function will guide clinical counselling and prevention efforts and inform public health policy decisions.

\section{METHODOLOGY}

\section{Study design and population}

The Canadian Longitudinal Study on Aging (CLSA) is a national stratified sample of 51338 participants aged
45-85 years at the time of recruitment (2012-2015) to be followed every 3 years, for at least 20 years or until death or loss to follow-up. The sampling design involved stratifying the population into different strata based on provinces, age groups $(45-54,55-64,65-74$ and $75+)$, sex and geographic area (residing near a CLSA data collection site vs not). Individuals residing in the three Canadian territories, in long-term care institutions, or on First Nation reserves, full-time members of the armed forces, individuals who are cognitively impaired or those unable to communicate in English or French were excluded from the study. The CLSA cohort has two components, the Tracking cohort $(\mathrm{n}=21$ 241) and the Comprehensive cohort ( $\mathrm{n}=30$ 097). In the CLSA Tracking cohort, participants were selected from all 10 Canadian provinces and measures were collected using a computer assisted telephone interview. In the Comprehensive cohort, participants were randomly selected from within $25-50 \mathrm{~km}$ of one of 11 CLSA data collection sites located in seven provinces. Information from the Comprehensive cohort participants was collected through in-person home interview, questionnaires and in-depth physical and biological assessments at a data collection site. All CLSA participants provided information on demographics, lifestyle and behaviour and social, physical and psychological health and health services utilisation. Details on the CLSA study design and methodology have been described previously. ${ }^{25}$ Of the 51338 participants, 44817 participants completed the first follow-up. Data from the Tracking $(\mathrm{n}=17$ 050) and Comprehensive cohorts $(\mathrm{n}=27$ 767) at the first follow-up were used to estimate the prevalence of e-cigarette ever use by sociodemographic characteristics in the population. Associations between e-cigarette ever use, conventional cigarette smoking and lung function impairment were based on the CLSA Comprehensive cohort since spirometry measures were collected for this cohort only. Of the 30097 participants recruited at baseline (2012-2015) in the Comprehensive cohort, spirometry measures were available for 20347 participants (online supplemental figure S1).

\section{Study measures}

Lung function

Spirometry was collected using the TruFlow Easy-on Spirometer (ndd Medical Technologies, Zürich, Switzerland) to measure the FVC and $\mathrm{FEV}_{1}{ }^{27}$ Trained staff provided instructions and coaching prior to asking participants to perform a maximal inspiratory and expiratory effort without bronchodilation. Up to a maximum of 8 efforts were encouraged to obtain at least three acceptable manoeuvres, which signifies the end of testing. As per the standardised procedure for collecting spirometry measurements, spirometry testing was not performed among participants who had a severe acute respiratory condition, were pregnant over 27 weeks, had an unstable heart condition, had average blood pressure of 200/120 $\mathrm{mm} \mathrm{Hg}$ or above, had thoracic, abdominal or cerebral aneurysm(s) present, had a heart surgery, a major surgery 
on chest or abdomen, detached retina or recent eye surgery or blood in sputum within the last 3 months. ${ }^{27}$ Further, quality assurance for spirometry data includes examining test results and evaluating them for evidence of technical errors. A spirometry test is valid if there are at least three acceptable manoeuvres with consistent or reproducible results for $\mathrm{FVC}$ and $\mathrm{FEV}_{1} \cdot{ }^{27}{ }^{28}$ Only participants with three acceptable manoeuvres and within $150 \mathrm{cc}$ of variability between the two highest $\mathrm{FEV}_{1}$ and FVC were selected for analysis. Further details on the spirometry procedures are described in the CLSA spirometry standard operating procedure documentation. ${ }^{27} \mathrm{~A}$ comparison of participants with acceptable manoeuvres and those with missing spirometry data for reasons other than contraindications showed greater proportion of participants who had missing spirometry data were in the oldest age group, were males, had no postsecondary education and had annual household income of less than $\$ 50000$ (online supplemental table S1).

The Global Lung Function Initiative (GLI) reference equations provide reliable spirometry prediction equation and include appropriate age dependent lower limit of normal (LLN). Therefore, GLI normative values for $\mathrm{FEV}_{1}, \mathrm{FVC}$ and $\mathrm{FEV}_{1} / \mathrm{FVC}$ ratio appropriate for age, sex, height and ethnicity were used to reliably interpret the severity of lung function impairment. The highest $\mathrm{FEV}_{1}$ and $\mathrm{FVC}$ and their ratio were transformed to percentage of predicted value (\% pred) for analysis. The latter provides an indication of the level of impairment compared with a normal population of similar age, sex, height and ethnicity. Lung function was further categorised as (1) obstructive if the $\mathrm{FEV}_{1} / \mathrm{FVC}$ ratio was less than the LLN, (2) restrictive if the FVC was less than LLN and $\mathrm{FEV}_{1} / \mathrm{FVC}$ ratio was greater than LLN or if the $\mathrm{FEV}_{1}$ was less than LLN and the $\mathrm{FEV}_{1} / \mathrm{FVC}$ ratio was greater than LLN and (3) normal if $\mathrm{FEV}_{1}, \mathrm{FVC}$, and $\mathrm{FEV}_{1} / \mathrm{FVC}$ ratio were greater than or equal to LLN for age, sex, height and ethnicity. ${ }^{29}$

\section{E-cigarette ever use and cigarette smoking}

E-cigarette ever use was assessed dichotomously as 'yes' or 'no' using responses to the following questions: 'Have you ever tried an electronic cigarette, also known as an e-cigarette?' and 'The last time you used an e-cigarette, did it contain nicotine?'. The intensity of conventional cigarette smoking was calculated in pack years (number of cigarettes smoked per day divided by 20 and multiplied by the number of years smoked) for ever-smokers (former daily smokers and current smokers). The number of conventional cigarettes smoked per day was assessed as an ordinal variable with categories of $1-5,6-10,11-15$, 16-20, 21-25 and 26+ cigarettes. For each category, the midpoint was used as the number of cigarettes smoked per day, and an exact number was used for participants who indicated smoking 26+ cigarettes. ${ }^{30}$ Participants who smoked less than 100 cigarettes in their lifetime were classified as 'never smokers'. In the analysis, cigarette smoking status was categorised as 'never smokers', 'less than 15 pack-years' and ' 15 or more pack-years'. Participants who were never daily smokers but indicated smoking at least 100 cigarettes in their lifetime were grouped with the 'less than 15 pack-years' category. ${ }^{30}$

\section{Sociodemographic and clinical characteristics}

Age was categorised into 45-54, 55-64, 65-74 and 75-85 years. Ethnic background was grouped as individuals identifying themselves as Europeans and non-Europeans. Self-reported highest level of education was categorised as no postsecondary education, postsecondary education below bachelor's degree, bachelor's degree and above postsecondary degree/diploma. Total annual household income was categorised as less than $\$ 20000, \$ 20000-\$ 49$ 999, \$50 000-\$99 999, \$100 000-\$149 999 and \$150 000 and above. Living area was classified as urban and rural, and number of individuals living in the same household was classified as living alone and not living alone. The number of chronic conditions from 10 disease categories including musculoskeletal, respiratory, cardiovascular, endocrine-metabolic, neurological, gastrointestinal, genitourinary, ophthalmological, renal and cancer were summed up and categorised into 'none', 'one', 'two' and 'three or more' chronic conditions. Participants were asked to report the chronic condition only if it was diagnosed by a health professional and if the condition had lasted or was expected to last at least 6 months.

\section{Statistical analysis}

Prevalence of adults who had ever tried an e-cigarette and whether their last used e-cigarette contained nicotine was examined by age groups, sex, ethnic background, education status, total annual household income and conventional cigarette smoking status using the Rao-Scott test used in complex samples and is equivalent to the $\chi^{2}$ test. Multinomial logistic regression was used to examine the association between e-cigarette ever use and lung function impairment adjusted for age, sex, ethnicity, education, annual household income, intensity of conventional cigarette smoking, living area, number of people living in the same household and number of chronic conditions. This study also examined if the association between e-cigarette ever use and lung function impairment varied by the intensity of conventional cigarette smoking status after adjusting for covariates. The number of participants who were never smokers but ever used an e-cigarette was small and was therefore grouped with the $0-14$ pack-years and ever used e-cigarette category. Since participants in certain subgroups in the population had varying probability of being selected into the CLSA sample, using sample weights would correct for the different selection probabilities. Therefore, all analyses were adjusted for the sampling design and performed using inflation and analytical weights provided by the CLSA, allowing results to reflect the distribution of e-cigarette ever use in the population of Canada. OR and 95\% CI were reported and analyses were carried out in SAS V.9.4 (Cary, North C, USA). 


\section{Patient and public involvement statement}

Patients or the public were not involved in the design, or conduct, or reporting, or dissemination plans of our research.

\section{RESULTS}

\section{Participants}

Table 1 presents the descriptive characteristics of participants by age and sex groups in the overall CLSA cohort. At baseline, $52.2 \%$ of participants were females, $95.2 \%$ were of European ethnicity, $68.1 \%$ of participants have attained an education of a bachelor's degree or above and $69.6 \%$ report annual household income of $\$ 50000$ or higher. Overall, 26.3\% of participants smoked 15 or more pack-years, $30.1 \%$ smoked less than 15 pack-years and $43.6 \%$ never smoked.

\section{E-cigarette ever use}

Figure 1 shows the prevalence of ever using an e-cigarette by demographic factors and cigarette smoking status across all participants and online supplemental figure S2 shows the distribution of participants who reported their last used e-cigarette contained nicotine. The results showed that $6.5 \%$ of adults aged $45-85$ years had ever used an e-cigarette and almost $70 \%$ of these individuals reported that their last used e-cigarette contained nicotine. The reporting of ever having used an e-cigarette and last used e-cigarette contained nicotine differed by age, sex, education and total annual household income. Males were more likely to have ever tried an e-cigarette and their last used e-cigarette was more likely to contain nicotine compared with females. Prevalence of ever using an e-cigarette declined as age increased, with approximately $9.5 \%$ among adults aged $45-54$ years to $1.7 \%$ among adults aged 75-85 years. Across all age groups about $64 \%-71 \%$ of individuals ever using an e-cigarette reported that their last used e-cigarette contained nicotine. Reporting of ever using an e-cigarette was higher among individuals with education below a bachelor's degree compared with those having at least a bachelor's degree. About 10.0\% of individuals with household income less than $\$ 20000$ reported ever using an e-cigarette, with use declining as annual household income increased. When examining e-cigarette use by conventional cigarette smoking status, $43.0 \%$ of daily cigarette smokers reported ever using an e-cigarette compared with $2.5 \%$ among those who never smoked cigarettes. However, among individuals who had never smoked a conventional cigarette, almost $60 \%$ reported their last used e-cigarette contained nicotine.

Association between e-cigarette ever use and obstructive, and restrictive lung function impairment

Analysis of the Comprehensive cohort data showed that $3.7 \%$ and $7.8 \%$ of participants had lung function impairment with obstructive and restrictive pattern, respectively. Table 2 presents the adjusted OR and 95\% CIs from analysis examining the association between e-cigarette ever use and obstructive and restrictive lung function impairment relative to normal lung function. E-cigarette ever use was associated with obstructive lung function impairment (OR: 2.10; 95\% CI 1.57 to 2.08) but not restrictive lung function impairment after adjusting for demographic factors, conventional cigarette smoking and chronic health conditions. The association between e-cigarette ever use and obstructive and restrictive lung impairment after adjusting for covariates was also examined among individuals with 0-14 pack-years and $15+$ pack years of smoking. The effects in the two conventional smoking groups were relatively different, suggesting a possible synergistic effect of exposure to both e-cigarette ever use and conventional cigarette use.

The association between e-cigarette ever use and obstructive and restrictive lung function impairment relative to normal lung function was examined by the intensity of conventional cigarette smoking after adjusting for covariates. The results showed that in comparison to never smokers and non-e-cigarette users, those who smoked 15 or more pack-years have 3.07 (95\% CI 2.45 to 3.86) times higher odds of obstructive lung function impairment, and the odds of obstructive lung function impairment were higher for cigarette smokers of 15 or more pack-years with e-cigarette ever use (OR: 7.43, 95\% CI 5.30 to 10.38). However, individuals who smoked 15 or more pack-years, with e-cigarette or without e-cigarette ever use had elevated and similar odds for restrictive lung function impairment. Among individuals who smoked 0-14 pack-years, ever e-cigarette users had higher, but non-statistically significant odds of obstructive lung function impairment, and lower odds of restrictive lung function impairment.

\section{DISCUSSION}

The current study reported on the prevalence and distribution of e-cigarette ever use and examined its association with lung function impairment in a large cohort of Canadian adults. Our results showed that $6.5 \%$ of Canadian adults aged 45-85 years reported ever using an e-cigarette (about $70 \%$ of whom used an e-cigarette containing nicotine), and the distribution varied by sociodemographic characteristics. Further, our results showed that ever use of an e-cigarette was associated with higher odds of obstructive lung function impairment. The odds of obstructive lung function impairment was highest among individuals with exposure of 15 or more pack-years and e-cigarette ever use compared with nonsmokers and non-e-cigarette users, whereas the odds of restrictive lung function impairment were similarly high among smokers of 15 or more pack-years irrespective of e-cigarette ever use.

The prevalence estimate of e-cigarette ever use in our study is comparable to estimate of $7.9 \%$ reported in a national survey conducted by Health Canada and Statistics Canada. ${ }^{31}$ Consistent with literature, we found the prevalence of e-cigarette ever use to vary by 
Table 1 Descriptive characteristics of participants by age groups and sex

\begin{tabular}{|c|c|c|c|c|c|c|c|c|c|c|}
\hline & \multicolumn{2}{|c|}{ Total population } & \multicolumn{2}{|c|}{ Ages 45-54 } & \multicolumn{2}{|c|}{ Ages 55-64 } & \multicolumn{2}{|c|}{ Ages 65-74 } & \multicolumn{2}{|c|}{ Ages 75-85 } \\
\hline & Male & Female & Male & Female & Male & Female & Male & Female & Male & Female \\
\hline $\mathrm{n}$ & $\begin{array}{l}21879 \\
(47.8)\end{array}$ & $\begin{array}{l}22937 \\
(52.2)\end{array}$ & $\begin{array}{l}3199 \\
(49.6)\end{array}$ & $\begin{array}{l}3399 \\
(50.4)\end{array}$ & $\begin{array}{l}6989 \\
(47.0)\end{array}$ & $\begin{array}{l}7762 \\
(53.0)\end{array}$ & $\begin{array}{l}6645 \\
(49.1)\end{array}$ & $\begin{array}{l}6657 \\
(50.9)\end{array}$ & $\begin{array}{l}5046 \\
(44.7)\end{array}$ & $\begin{array}{l}5119 \\
(55.3)\end{array}$ \\
\hline $\begin{array}{l}\text { European ethnicity, } \\
\mathrm{n}(\%)\end{array}$ & $\begin{array}{l}20739 \\
(94.9)\end{array}$ & $\begin{array}{l}21983 \\
(95.5)\end{array}$ & $\begin{array}{l}2921 \\
(92.2)\end{array}$ & $\begin{array}{l}3189 \\
(93.0)\end{array}$ & $\begin{array}{l}6622 \\
(94.7)\end{array}$ & $\begin{array}{l}7366 \\
(94.9)\end{array}$ & $\begin{array}{l}6342 \\
(96.6)\end{array}$ & $\begin{array}{l}6434 \\
(97.0)\end{array}$ & $\begin{array}{l}4854 \\
(96.8)\end{array}$ & $\begin{array}{l}4994 \\
(97.8)\end{array}$ \\
\hline \multicolumn{11}{|c|}{ Education, $\mathrm{n}(\%)$} \\
\hline $\begin{array}{l}\text { No } \\
\text { postsecondary } \\
\text { education }\end{array}$ & $\begin{array}{l}1221 \\
(17.8)\end{array}$ & $\begin{array}{l}1449 \\
(18.6)\end{array}$ & $\begin{array}{l}78 \\
(8.3)\end{array}$ & $\begin{array}{l}63 \\
(7.1)\end{array}$ & $\begin{array}{l}254 \\
(16.4)\end{array}$ & $\begin{array}{l}251 \\
(13.0)\end{array}$ & $\begin{array}{l}328 \\
(18.4)\end{array}$ & $\begin{array}{l}424 \\
(22.5)\end{array}$ & $\begin{array}{l}561 \\
(35.0)\end{array}$ & $\begin{array}{l}711 \\
(39.7)\end{array}$ \\
\hline $\begin{array}{l}\text { Diploma/ } \\
\text { certificate below } \\
\text { bachelor's }\end{array}$ & $\begin{array}{l}2074 \\
(12.4)\end{array}$ & $\begin{array}{l}2661 \\
(15.0)\end{array}$ & $\begin{array}{l}208 \\
(9.3)\end{array}$ & $\begin{array}{l}249 \\
(11.7)\end{array}$ & $\begin{array}{l}708 \\
(14.4)\end{array}$ & $\begin{array}{l}893 \\
(17.0)\end{array}$ & $\begin{array}{l}626 \\
(13.4)\end{array}$ & $\begin{array}{l}808 \\
(15.9)\end{array}$ & $\begin{array}{l}532 \\
(11.1)\end{array}$ & $\begin{array}{l}711 \\
(12.4)\end{array}$ \\
\hline $\begin{array}{l}\text { Bachelor's } \\
\text { degree }\end{array}$ & $\begin{array}{l}1571 \\
(8.9)\end{array}$ & $\begin{array}{l}1741 \\
(9.2)\end{array}$ & $\begin{array}{l}166 \\
(8.5)\end{array}$ & $\begin{array}{l}181 \\
(7.4)\end{array}$ & $\begin{array}{l}498 \\
(9.3)\end{array}$ & $\begin{array}{l}599 \\
(10.5)\end{array}$ & $\begin{array}{l}509 \\
(9.3)\end{array}$ & $\begin{array}{l}512 \\
(9.5)\end{array}$ & $\begin{array}{l}398 \\
(8.0)\end{array}$ & $\begin{array}{l}449 \\
(8.2)\end{array}$ \\
\hline $\begin{array}{l}\text { Above bachelor's } \\
\text { degree }\end{array}$ & $\begin{array}{l}16956 \\
(60.8)\end{array}$ & $\begin{array}{l}17040 \\
(57.3)\end{array}$ & $\begin{array}{l}2747 \\
(73.9)\end{array}$ & $\begin{array}{l}2903 \\
(73.8)\end{array}$ & $\begin{array}{l}5517 \\
(59.9)\end{array}$ & $\begin{array}{l}6007 \\
(59.5)\end{array}$ & $\begin{array}{l}5167 \\
(58.8)\end{array}$ & $\begin{array}{l}4900 \\
(52.0)\end{array}$ & $\begin{array}{l}3525 \\
(45.8)\end{array}$ & $\begin{array}{l}3230 \\
(38.6)\end{array}$ \\
\hline \multicolumn{11}{|c|}{ Annual household income, $\mathrm{n}(\%)$} \\
\hline$<\$ 20000$ & $\begin{array}{l}678 \\
(3.5)\end{array}$ & $\begin{array}{l}1405 \\
(7.0)\end{array}$ & $\begin{array}{l}74 \\
(2.8)\end{array}$ & $\begin{array}{l}102 \\
(4.4)\end{array}$ & $\begin{array}{l}234 \\
(3.7)\end{array}$ & $\begin{array}{l}362 \\
(4.9)\end{array}$ & $\begin{array}{l}217 \\
(3.7)\end{array}$ & $\begin{array}{l}444 \\
(8.7)\end{array}$ & $\begin{array}{l}153 \\
(3.6)\end{array}$ & $\begin{array}{l}497 \\
(13.3)\end{array}$ \\
\hline$\$ 20000-<50000$ & $\begin{array}{l}3995 \\
(21.8)\end{array}$ & $\begin{array}{l}5934 \\
(28.2)\end{array}$ & $\begin{array}{l}230 \\
(9.4)\end{array}$ & $\begin{array}{l}361 \\
(10.8)\end{array}$ & $\begin{array}{l}855 \\
(15.8)\end{array}$ & $\begin{array}{l}1385 \\
(21.7)\end{array}$ & $\begin{array}{l}1468 \\
(32.6)\end{array}$ & $\begin{array}{l}2160 \\
(38.4)\end{array}$ & $\begin{array}{l}1442 \\
(37.3)\end{array}$ & $\begin{array}{l}2028 \\
(53.0)\end{array}$ \\
\hline $\begin{array}{l}\$ 50000-<100 \\
000\end{array}$ & $\begin{array}{l}7727 \\
(36.4)\end{array}$ & $\begin{array}{l}7397 \\
(35.0)\end{array}$ & $\begin{array}{l}772 \\
(26.8)\end{array}$ & $\begin{array}{l}949 \\
(32.0)\end{array}$ & $\begin{array}{l}2143 \\
(35.7)\end{array}$ & $\begin{array}{l}2687 \\
(37.8)\end{array}$ & $\begin{array}{l}2801 \\
(43.2)\end{array}$ & $\begin{array}{l}2378 \\
(38.8)\end{array}$ & $\begin{array}{l}2011 \\
(41.8)\end{array}$ & $\begin{array}{l}1383 \\
(26.3)\end{array}$ \\
\hline $\begin{array}{l}\$ 100000-<150 \\
000\end{array}$ & $\begin{array}{l}4395 \\
(20.1)\end{array}$ & $\begin{array}{l}3414 \\
(17.0)\end{array}$ & $\begin{array}{l}839 \\
(27.0)\end{array}$ & $\begin{array}{l}849 \\
(26.7)\end{array}$ & $\begin{array}{l}1710 \\
(24.0)\end{array}$ & $\begin{array}{l}1542 \\
(20.7)\end{array}$ & $\begin{array}{l}1170 \\
(13.7)\end{array}$ & $\begin{array}{l}734 \\
(10.3)\end{array}$ & $\begin{array}{l}676 \\
(10.7)\end{array}$ & $\begin{array}{l}289 \\
(4.8)\end{array}$ \\
\hline$\geq \$ 150000$ & $\begin{array}{l}3906 \\
(18.2)\end{array}$ & $\begin{array}{l}2710 \\
(12.8)\end{array}$ & $\begin{array}{l}1172 \\
(33.9)\end{array}$ & $\begin{array}{l}985 \\
(26.2)\end{array}$ & $\begin{array}{l}1735 \\
(20.9)\end{array}$ & $\begin{array}{l}1274 \\
(15.0)\end{array}$ & $\begin{array}{l}647 \\
(6.7)\end{array}$ & $\begin{array}{l}335 \\
(3.8)\end{array}$ & $\begin{array}{l}352 \\
(6.6)\end{array}$ & $\begin{array}{l}116 \\
(2.6)\end{array}$ \\
\hline \multicolumn{11}{|l|}{ Living area, $\mathrm{n}(\%)$} \\
\hline Urban & $\begin{array}{l}19516 \\
(85.8)\end{array}$ & $\begin{array}{l}20567 \\
(86.0)\end{array}$ & $\begin{array}{l}2887 \\
(90.2)\end{array}$ & $\begin{array}{l}3027 \\
(87.0)\end{array}$ & $\begin{array}{l}6203 \\
(84.3)\end{array}$ & $\begin{array}{l}6883 \\
(84.6)\end{array}$ & $\begin{array}{l}5882 \\
(84.0)\end{array}$ & $\begin{array}{l}5956 \\
(86.1)\end{array}$ & $\begin{array}{l}4544 \\
(85.3)\end{array}$ & $\begin{array}{l}4701 \\
(87.6)\end{array}$ \\
\hline Rural & $\begin{array}{l}2347 \\
(14.2)\end{array}$ & $\begin{array}{l}2355 \\
(14.0)\end{array}$ & $\begin{array}{l}312 \\
(9.9)\end{array}$ & $\begin{array}{l}367 \\
(13.0)\end{array}$ & $\begin{array}{l}784 \\
(15.6)\end{array}$ & $\begin{array}{l}877 \\
(15.4)\end{array}$ & $\begin{array}{l}756 \\
(16.0)\end{array}$ & $\begin{array}{l}694 \\
(13.9)\end{array}$ & $\begin{array}{l}495 \\
(14.7)\end{array}$ & $\begin{array}{l}417 \\
(12.4)\end{array}$ \\
\hline \multicolumn{11}{|c|}{ Number of individuals living in the same household, $n(\%)$} \\
\hline Living alone & $\begin{array}{l}3758 \\
(13.9)\end{array}$ & $\begin{array}{l}6946 \\
(21.4)\end{array}$ & $\begin{array}{l}335 \\
(9.9)\end{array}$ & $\begin{array}{l}404 \\
(8.0)\end{array}$ & $\begin{array}{l}1068 \\
(13.1)\end{array}$ & $\begin{array}{l}1576 \\
(14.6)\end{array}$ & $\begin{array}{l}1138 \\
(14.9)\end{array}$ & $\begin{array}{l}2222 \\
(25.9)\end{array}$ & $\begin{array}{l}1217 \\
(20.2)\end{array}$ & $\begin{array}{l}2744 \\
(47.1)\end{array}$ \\
\hline Not living alone & $\begin{array}{l}17731 \\
(86.1)\end{array}$ & $\begin{array}{l}15529 \\
(78.6)\end{array}$ & $\begin{array}{l}2801 \\
(90.1)\end{array}$ & $\begin{array}{l}2919 \\
(92.0)\end{array}$ & $\begin{array}{l}5810 \\
(86.9)\end{array}$ & $\begin{array}{l}6049 \\
(85.4)\end{array}$ & $\begin{array}{l}5413 \\
(85.1)\end{array}$ & $\begin{array}{l}4336 \\
(74.1)\end{array}$ & $\begin{array}{l}3707 \\
(79.8)\end{array}$ & $\begin{array}{l}2225 \\
(52.9)\end{array}$ \\
\hline \multicolumn{11}{|c|}{ Cigarette smoking, n (\%) } \\
\hline Never & $\begin{array}{l}9421 \\
(40.3)\end{array}$ & $\begin{array}{l}11594 \\
(46.6)\end{array}$ & $\begin{array}{l}1904 \\
(53.6)\end{array}$ & $\begin{array}{l}1840 \\
(49.6)\end{array}$ & $\begin{array}{l}3232 \\
(40.0)\end{array}$ & $\begin{array}{l}3722 \\
(41.5)\end{array}$ & $\begin{array}{l}2434 \\
(32.7)\end{array}$ & $\begin{array}{l}3293 \\
(46.7)\end{array}$ & $\begin{array}{l}1851 \\
(33.6)\end{array}$ & $\begin{array}{l}2739 \\
(53.7)\end{array}$ \\
\hline 0-14 pack-years & $\begin{array}{l}6478 \\
(28.8)\end{array}$ & $\begin{array}{l}7022 \\
(31.3)\end{array}$ & $\begin{array}{l}847 \\
(28.5)\end{array}$ & $\begin{array}{l}1095 \\
(32.7)\end{array}$ & $\begin{array}{l}2058 \\
(28.8)\end{array}$ & $\begin{array}{l}2554 \\
(35.9)\end{array}$ & $\begin{array}{l}2059 \\
(28.9)\end{array}$ & $\begin{array}{l}1955 \\
(27.2)\end{array}$ & $\begin{array}{l}1514 \\
(29.0)\end{array}$ & $\begin{array}{l}1418 \\
(25.5)\end{array}$ \\
\hline$\geq 15$ pack-years & $\begin{array}{l}58871 \\
(30.9)\end{array}$ & $\begin{array}{l}4178 \\
(22.1)\end{array}$ & $\begin{array}{l}440 \\
(17.9)\end{array}$ & $\begin{array}{l}452 \\
(17.8)\end{array}$ & $\begin{array}{l}1671 \\
(31.2)\end{array}$ & $\begin{array}{l}1449 \\
(22.6)\end{array}$ & $\begin{array}{l}2115 \\
(38.4)\end{array}$ & $\begin{array}{l}1368 \\
(26.1)\end{array}$ & $\begin{array}{l}1645 \\
(37.4)\end{array}$ & $\begin{array}{l}909 \\
(20.8)\end{array}$ \\
\hline \multicolumn{11}{|c|}{ Number of chronic conditions, $\mathrm{n}(\%)$} \\
\hline None & $\begin{array}{l}3793 \\
(19.9)\end{array}$ & $\begin{array}{l}2797 \\
(13.5)\end{array}$ & $\begin{array}{l}1187 \\
(36.4)\end{array}$ & $\begin{array}{l}940 \\
(26.5)\end{array}$ & $\begin{array}{l}1682 \\
(22.9)\end{array}$ & $\begin{array}{l}1322 \\
(16.5)\end{array}$ & $\begin{array}{l}730 \\
(10.6)\end{array}$ & $\begin{array}{l}428 \\
(5.9)\end{array}$ & $\begin{array}{l}194 \\
(3.4)\end{array}$ & $\begin{array}{l}107 \\
(1.6)\end{array}$ \\
\hline One & $\begin{array}{l}4631 \\
(22.9)\end{array}$ & $\begin{array}{l}4042 \\
(18.8)\end{array}$ & $\begin{array}{l}944 \\
(30.0)\end{array}$ & $\begin{array}{l}923 \\
(26.8)\end{array}$ & $\begin{array}{l}1852 \\
(26.4)\end{array}$ & $\begin{array}{l}1728 \\
(21.8)\end{array}$ & $\begin{array}{l}1295 \\
(18.8)\end{array}$ & $\begin{array}{l}988 \\
(14.9)\end{array}$ & $\begin{array}{l}540 \\
(10.4)\end{array}$ & $\begin{array}{l}403 \\
(7.4)\end{array}$ \\
\hline Two & $\begin{array}{l}4234 \\
(19.1)\end{array}$ & $\begin{array}{l}4185 \\
(18.5)\end{array}$ & $\begin{array}{l}544 \\
(17.5)\end{array}$ & $\begin{array}{l}679 \\
(20.3)\end{array}$ & $\begin{array}{l}1382 \\
(19.6)\end{array}$ & $\begin{array}{l}1594 \\
(20.6)\end{array}$ & $\begin{array}{l}1386 \\
(19.8)\end{array}$ & $\begin{array}{l}1228 \\
(16.7)\end{array}$ & $\begin{array}{l}922 \\
(19.2)\end{array}$ & $\begin{array}{l}684 \\
(14.5)\end{array}$ \\
\hline
\end{tabular}


Table 1 Continued

\begin{tabular}{|c|c|c|c|c|c|c|c|c|c|c|}
\hline & \multicolumn{2}{|c|}{ Total population } & \multicolumn{2}{|c|}{ Ages 45-54 } & \multicolumn{2}{|c|}{ Ages 55-64 } & \multicolumn{2}{|c|}{ Ages 65-74 } & \multicolumn{2}{|c|}{ Ages 75-85 } \\
\hline & Male & Female & Male & Female & Male & Female & Male & Female & Male & Female \\
\hline & $\begin{array}{l}8967 \\
(38.1)\end{array}$ & $\begin{array}{l}11609 \\
(49.2)\end{array}$ & $\begin{array}{l}483 \\
(16.1)\end{array}$ & $\begin{array}{l}803 \\
(26.5)\end{array}$ & $\begin{array}{l}2010 \\
(31.1)\end{array}$ & $\begin{array}{l}3034 \\
(41.0)\end{array}$ & $\begin{array}{l}3168 \\
(50.7)\end{array}$ & $\begin{array}{l}3957 \\
(62.5)\end{array}$ & $\begin{array}{l}3306 \\
(67.0)\end{array}$ & $\begin{array}{l}3815 \\
(76.5)\end{array}$ \\
\hline
\end{tabular}

sociodemographic characteristics with higher prevalence among males, those younger than 65 years, having lower education attainment and lower total annual household income. ${ }^{432}$ In accordance with many other studies, we also found that e-cigarette ever use was more prevalent among smokers, particularly among smokers who smoked 15 or more pack-years. ${ }^{40}$ Together, these findings suggest that e-cigarettes are being used as a smoking cessation tool. ${ }^{33}$

Our results also showed that individuals who reported ever using an e-cigarette had significantly higher odds of obstructive lung function impairment compared with no e-cigarette use, controlling for conventional cigarette smoking, chronic health conditions and sociodemographic factors. This finding is consistent with the findings from animal ${ }^{64-38}$ studies and short-term exposure human studies. ${ }^{39-42}$ To date, there are no data on the long-term effects of e-cigarette exposure, which is urgently needed given the rising rates of e-cigarette use. Results from cell studies indicate that emissions from e-cigarettes are associated with the generation of reactive oxygen species, which result in oxidative stress and may play a role in initiating proinflammatory responses and

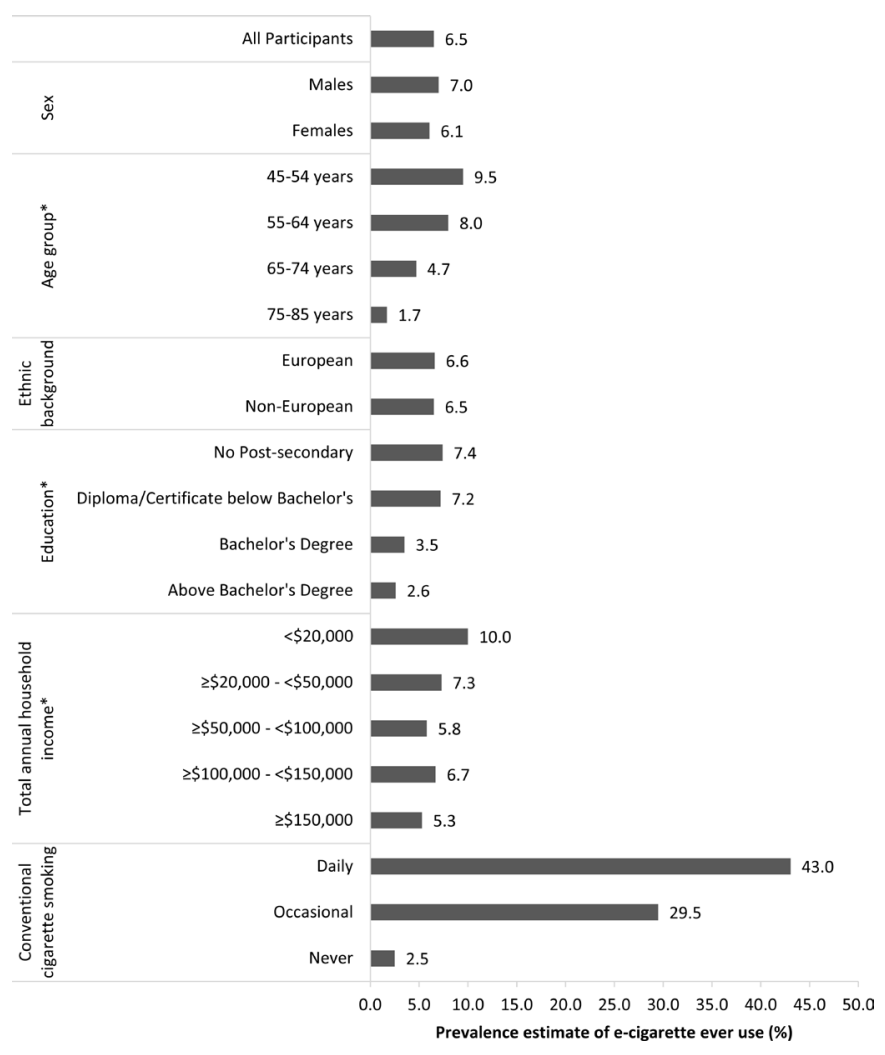

Figure 1 Percentage of adults who ever used an e-cigarette by demographic factors and cigarette smoking status. affecting airway cells. ${ }^{43}$ Inhaling aerosols from e-cigarettes were also found to be associated with increased lung flow resistance, which precedes changes in peak expiratory flow and $\mathrm{FEV}_{1}{ }^{15}{ }^{44} 45$ Further, research has shown acute exposure to e-cigarette with and without nicotine to be associated with a higher fraction of exhaled nitric oxide and lower vital capacity among occasional smokers, which suggests that non-nicotine toxicants also impact lung inflammation and function. ${ }^{46}{ }^{47}$ However, there was no association between e-cigarette ever use and restrictive lung function after adjusting for conventional cigarette smoking status. E-cigarettes are perceived to be effective for reducing or quitting smoking. ${ }^{48}$ Therefore, heavy intensity smokers may be more likely to use e-cigarettes for this purpose as there is some evidence that e-cigarettes can deliver nicotine into the bloodstream and lower nicotine withdrawal effects. ${ }^{49}$

Further, our results showed that the association between e-cigarette ever use and obstructive and restrictive lung function impairment differed by the intensity of the conventional cigarette use. As expected, individuals who smoked 15 or more pack-years had higher odds of obstructive and restrictive lung function impairment when compared with never smokers and non-e-cigarette users. Interestingly, the odds of obstructive lung function impairment was further elevated among individuals who smoked 15 or more pack-years and used e-cigarettes compared with never smokers and non-e-cigarette users. This finding is consistent with previous research that found dual use of e-cigarettes and tobacco cigarettes to have more detrimental effects on lung function than using either product alone. ${ }^{13}$ The results suggest that people who smoked 15 or more pack-years had greater lung tissue damage and were more sensitive to aerosol from e-cigarettes. It is also possible that these individuals may have used e-cigarettes more frequently or intensely because of higher nicotine dependence, and perhaps, to assist with quitting or reducing smoking. However, it is possible that the nicotine from e-cigarettes does not satisfy dual users' nicotine need enough to help them quit or reduce their use of tobacco cigarettes, and the additional exposure to nicotine and other toxicants from e-cigarettes may further contribute to the adverse effects on lung function. ${ }^{105051}$ Further, although we accounted for intensity of conventional cigarette smoking by creating a pack-years variable, it is possible that the group with both exposures (smokers who smoked 15 or more pack-years and ever used e-cigarettes) had a greater proportion of individuals with higher intensity of conventional cigarette smoking. It is also likely that smokers who intend to quit 
Table 2 Association between ever using an e-cigarette and obstructive and restrictive lung function impairment relative to normal lung function $(n=19057)$

\begin{tabular}{|c|c|c|c|c|}
\hline & \multicolumn{2}{|c|}{$\begin{array}{l}\text { Obstructive lung function } \\
\text { impairment }\end{array}$} & \multicolumn{2}{|c|}{$\begin{array}{l}\text { Restrictive lung function } \\
\text { impairment }\end{array}$} \\
\hline & $\mathbf{O R}^{*}$ & $95 \% \mathbf{C l}$ & $\mathbf{O R}^{*}$ & $95 \% \mathbf{C l}$ \\
\hline \multicolumn{5}{|l|}{ Model $1^{*}$} \\
\hline E-cigarette ever use vs e-cigarette never use & 2.10 & 1.57 to 2.08 & 1.02 & 0.80 to 1.31 \\
\hline \multicolumn{5}{|l|}{ Model $2^{*}$} \\
\hline $\begin{array}{l}\text { E-cigarette ever use vs e-cigarette never use among } \\
\text { smokers with } 15+\text { pack years }\end{array}$ & 2.40 & 1.69 to 3.41 & 1.24 & 0.92 to 1.67 \\
\hline $\begin{array}{l}\text { E-cigarette ever use vs e-cigarette never use among } \\
\text { smokers with 0-14 pack-years }\end{array}$ & 1.81 & 0.93 to 3.52 & 0.74 & 0.42 to 1.30 \\
\hline \multicolumn{5}{|l|}{ Model 3* } \\
\hline $15+$ pack years and e-cigarette ever use vs None & 7.43 & 5.30 to 10.38 & 2.23 & 1.68 to 2.96 \\
\hline $15+$ pack years and no e-cigarette use vs None & 3.07 & 2.45 to 3.86 & 1.82 & 1.56 to 2.12 \\
\hline $0-14$ pack-years and e-cigarette ever use vs None & 1.60 & 0.85 to 3.01 & 0.54 & 0.33 to 0.90 \\
\hline 0-14 pack-years and no e-cigarette use vs None & 1.05 & 0.82 to 1.35 & 0.79 & 0.67 to 0.92 \\
\hline
\end{tabular}

*The OR estimates have been adjusted for covariates including age, sex, ethnic background, education status, total annual household income, urban/rural area of residence, number of individuals living in the household and number of chronic conditions and conventional cigarette smoking (in Model 1). Model 2 presents the OR estimates and 95\% $\mathrm{Cl}$ for e-cigarette ever use in each of the conventional smoking categories.

may have recently initiated e-cigarette use, and therefore future research should consider the frequency, intention and duration of e-cigarette use when assessing its impact on health outcomes.

\section{Strengths and limitations of this study}

This study has some limitations that should be considered when interpreting the results. A major limitation is that e-cigarette use was measured using a single question that assessed whether participants ever used an e-cigarette. Information on the frequency, intensity and duration of e-cigarette use, method of e-cigarette delivery, type of e-cigarette liquid and dose of nicotine or flavours was unavailable and not assessed. Spirometry testing was not performed in participants who were identified to have contraindications for spirometry testing. Further, participants who did not have at least three acceptable manoeuvres were excluded from the analysis, which may impact the validity of the findings. According to the standardised procedure for collecting spirometry measurements, a spirometry test is valid if there are at least three acceptable manoeuvres with consistent or reproducible results for FVC and $\mathrm{FEV}_{1}{ }^{27}$ To ensure that our spirometry data were valid and not impacted by technical errors, we only included participants with three acceptable manoeuvres. However, a comparison of participants with valid spirometry data and those with missing spirometry data for reasons other than contraindications showed that a greater proportion of participants who had missing spirometry data were in the oldest age group, were males, had no postsecondary education and had annual household income of less than $\$ 50000$, which may affect the validity of our findings. Also, reverse causality is an important limitation as the temporality of association between e-cigarette use and lung function impairment cannot be established due to the cross-sectional nature of the data. It is not clear if conventional cigarette smokers with lung function impairment were more likely to initiate e-cigarette use or if e-cigarette use contributed to lung function impairment. Longitudinal studies are needed to examine the impact of e-cigarette use on lung function. Nevertheless, this study included a nationally generalisable sample and is the largest population-based study to report the prevalence of e-cigarette use among different socioeconomic groups and examine its association with lung function impairment among older adults.

\section{CONCLUSION}

In conclusion, the current study identified sociodemographic characteristics associated with e-cigarette ever use, which will be useful in understanding and reducing health disparities in the population. Evidence also indicates high prevalence of e-cigarette ever use among smokers. Ever use of an e-cigarette was associated with lung function impairment, suggesting that e-cigarette use may be adding to the respiratory and other chronic disease burden in the population. Further research is needed to understand the association between e-cigarette use and respiratory health, both among smokers and non-smokers.

Contributors DJ, MD, SK and PR were involved in the conceptualisation and design of the study. DJ and PR conducted the data analyses. DJ drafted the manuscript. All authors contributed to the interpretation of the data, provided critical 
revisions of the manuscript and approved the final version to be published. PR will serve as a guarantor for the contents of this article.

Funding This research was made possible using the data/biospecimens collected by the Canadian Longitudinal Study on Aging (CLSA). Funding for the Canadian Longitudinal Study on Aging (CLSA) is provided by the Government of Canada through the Canadian Institutes of Health Research (CIHR) under grant reference: LSA 94473 and the Canada Foundation for Innovation and provincial governments (Newfoundland, Nova Scotia, Quebec, Ontario, Manitoba, Alberta and British Columbia). This research has been conducted using the Baseline Tracking Dataset version 3.6, Comprehensive Dataset version 4.2, Follow-up 1 Tracking Dataset version 2.0, Comprehensive Dataset version 3.0, CLSA Sample Weights Version 1.2 under Application Number 1909036. The CLSA is led by Drs Parminder Raina, Christina Wolfson and Susan Kirkland. Parminder Raina holds the Raymond and Margaret Labarge Chair in Optimal Aging and Knowledge Application for Optimal Aging, is the Director of the McMaster Institute for Research on Aging and the Labarge Centre for Mobility in Aging and holds a Tier 1 Canada Research Chair in Geroscience.

Competing interests None declared.

Patient consent for publication Not applicable.

Ethics approval This study was approved by the Hamilton Integrated Research Ethics Board (ethics approval number 09-213 and 10-423). The participant data were deidentified at the CLSA Data Curation Centre prior to their release to the study team.

Provenance and peer review Not commissioned; externally peer reviewed.

Data availability statement Data may be obtained from a third party and are not publicly available. Data are available from the Canadian Longitudinal Study on Aging (www.clsa-elcv.ca) for researchers who meet the criteria for access to de-identified CLSA data.

Supplemental material This content has been supplied by the author(s). It has not been vetted by BMJ Publishing Group Limited (BMJ) and may not have been peer-reviewed. Any opinions or recommendations discussed are solely those of the author(s) and are not endorsed by BMJ. BMJ disclaims all liability and responsibility arising from any reliance placed on the content. Where the content includes any translated material, BMJ does not warrant the accuracy and reliability of the translations (including but not limited to local regulations, clinical guidelines, terminology, drug names and drug dosages), and is not responsible for any error and/or omissions arising from translation and adaptation or otherwise.

Open access This is an open access article distributed in accordance with the Creative Commons Attribution Non Commercial (CC BY-NC 4.0) license, which permits others to distribute, remix, adapt, build upon this work non-commercially, and license their derivative works on different terms, provided the original work is properly cited, appropriate credit is given, any changes made indicated, and the use is non-commercial. See: http://creativecommons.org/licenses/by-nc/4.0/.

\section{ORCID iD}

Divya Joshi http://orcid.org/0000-0003-3190-8866

\section{REFERENCES}

1 GBD Chronic Respiratory Disease Collaborators. Prevalence and attributable health burden of chronic respiratory diseases, 19902017: a systematic analysis for the global burden of disease study 2017. Lancet Respir Med 2020;8:585-96.

2 Eaton D, Kwan L, Stratton K. Chapter 5. toxicology of e-cigarette constituents. In: Public health consequences of e-cigarettes: a consensus study of the National academies of sciences, engineering, and medicine, 2018: 155-215.

3 Ontario Agency for Health Protection and Promotion (Public Health Ontario). Ontario tobacco monitoring report 2018. technical supplement to chapter 6: electronic cigarettes. Toronto, ON: Queen's Printer for Ontario, 2019.

4 Reid JL, Rynard VL, Czoli CD, et al. Who is using e-cigarettes in Canada? Nationally representative data on the prevalence of ecigarette use among Canadians. Prev Med 2015;81:180-3.

5 Government of Canada. Canadian tobacco, alcohol and drugs survey (CTADS): summary of results for 2017, 2019.

6 Garcia-Arcos I, Geraghty P, Baumlin N, et al. Chronic electronic cigarette exposure in mice induces features of COPD in a nicotinedependent manner. Thorax 2016;71:1119-29.
7 Glynos C, Bibli S-I, Katsaounou P, et al. Comparison of the effects of e-cigarette vapor with cigarette smoke on lung function and inflammation in mice. Am J Physiol Lung Cell Mol Physiol 2018;315:L662-72.

8 Meo SA, Ansary MA, Barayan FR, et al. Electronic cigarettes: impact on lung function and fractional exhaled nitric oxide among healthy adults. Am J Mens Health 2019;13:1557988318806073.

9 Yao T, Max W, Sung H-Y, et al. Relationship between spending on electronic cigarettes, 30-day use, and disease symptoms among current adult cigarette smokers in the U.S. PLoS One 2017;12:e0187399.

10 Hedman L, Backman H, Stridsman C, et al. Association of electronic cigarette use with smoking habits, demographic factors, and respiratory symptoms. JAMA Netw Open 2018;1:e180789.

11 Wills TA, Pagano I, Williams RJ, et al. E-Cigarette use and respiratory disorder in an adult sample. Drug Alcohol Depend 2019;194:363-70.

12 Bowler RP, Hansel NN, Jacobson S, et al. Electronic cigarette use in US adults at risk for or with COPD: analysis from two observational cohorts. J Gen Intern Med 2017;32:1315-22.

13 Bhatta DN, Glantz SA. Association of e-cigarette use with respiratory disease among adults: a longitudinal analysis. Am J Prev Med 2020;58:182-90.

14 Flouris AD, Chorti MS, Poulianiti KP, et al. Acute impact of active and passive electronic cigarette smoking on serum cotinine and lung function. Inhal Toxicol 2013;25:91-101.

15 Vardavas Cl, Anagnostopoulos N, Kougias M, et al. Short-Term pulmonary effects of using an electronic cigarette: impact on respiratory flow resistance, impedance, and exhaled nitric oxide. Chest 2012;141:1400-6.

16 Bullen C, Howe C, Laugesen M, et al. Electronic cigarettes for smoking cessation: a randomised controlled trial. Lancet 2013;382:1629-37.

17 Fairchild AL, Bayer R, Colgrove J. The renormalization of smoking? E-cigarettes and the tobacco "endgame". N Engl J Med 2014;370:293-5.

18 Abrams DB. Promise and peril of e-cigarettes: can disruptive technology make cigarettes obsolete? JAMA 2014;311:135-6.

19 Fagerström KO, Bridgman K. Tobacco harm reduction: the need for new products that can compete with cigarettes. Addict Behav 2014;39:507-11.

20 Sweanor D, Alcabes P, Drucker E. Tobacco harm reduction: how rational public policy could transform a pandemic. Int J Drug Policy 2007;18:70-4.

21 Osei AD, Mirbolouk M, Orimoloye OA, et al. Association between e-cigarette use and cardiovascular disease among never and current Combustible-Cigarette smokers. Am J Med 2019;132:949-54.

$22 \mathrm{Kim} \mathrm{T}$, Kang J. Association between dual use of e-cigarette and cigarette and chronic obstructive pulmonary disease: an analysis of a nationwide representative sample from 2013 to 2018. BMC Pulm Med 2021;21:231.

23 Farsalinos KE, Romagna G, Tsiapras D, et al. Characteristics, perceived side effects and benefits of electronic cigarette use: a worldwide survey of more than 19,000 consumers. Int J Environ Res Public Health 2014;11:4356-73.

24 Polosa R, Morjaria JB, Prosperini U, et al. COPD smokers who switched to e-cigarettes: health outcomes at 5-year follow up. Ther Adv Chronic Dis 2020;11:2040622320961617.

25 Raina PS, Wolfson C, Kirkland SA, et al. The Canadian longitudinal study on aging (CLSA). Can J Aging 2009;28:221-9.

26 Raina P, Wolfson C, Kirkland S, et al. Cohort profile: the Canadian longitudinal study on aging (CLSA). Int J Epidemiol 2019;48:1752-3

27 Canadian longitudinal study on aging (CLSA). spirometry 2017.

28 Miller MR, Hankinson J, Brusasco V, et al. Standardisation of spirometry. Eur Respir J 2005;26:319-38.

29 Quanjer PH, Stanojevic S, Cole TJ, et al. Multi-ethnic reference values for spirometry for the 3-95-yr age range: the global lung function 2012 equations. Eur Respir J 2012;40:1324-43.

30 Dogra S, Good J, Buman MP, et al. Movement behaviours are associated with lung function in middle-aged and older adults: a cross-sectional analysis of the Canadian longitudinal study on aging. BMC Public Health 2018;18:818.

31 Reid J, Hammond D, Tariq U. Tobacco use in Canada: patterns and trends, 2019 edition. Waterloo, ON: University of Waterloo-Propel Centre for Population Health Impact, 2020.

32 Schoenborn CA, Gindi RM. Electronic cigarette use among adults: United States, 2014. NCHS Data Brief 2015;217:1-8.

33 Delnevo CD, Giovenco DP, Steinberg MB, et al. Patterns of electronic cigarette use among adults in the United States. Nicotine Tob Res 2016;18:715-9. 
34 Sussan TE, Gajghate S, Thimmulappa RK, et al. Exposure to electronic cigarettes impairs pulmonary anti-bacterial and anti-viral defenses in a mouse model. PLoS One 2015;10:e0116861.

35 Chun LF, Moazed F, Calfee CS, et al. Pulmonary toxicity of ecigarettes. Am J Physiol Lung Cell Mol Physiol 2017;313:L193-206.

36 Moretto N, Volpi G, Pastore F, et al. Acrolein effects in pulmonary cells: relevance to chronic obstructive pulmonary disease. Ann N Y Acad Sci 2012;1259:39-46.

37 Reinikovaite V, Rodriguez IE, Karoor V, et al. The effects of electronic cigarette vapour on the lung: direct comparison to tobacco smoke. Eur Respir J 2018;51. doi:10.1183/13993003.01661-2017. [Epub ahead of print: 0404 2018].

38 Crotty Alexander LE, Drummond CA, Hepokoski M, et al. Chronic inhalation of e-cigarette vapor containing nicotine disrupts airway barrier function and induces systemic inflammation and multiorgan fibrosis in mice. Am J Physiol Regul Integr Comp Physiol 2018;314:R834-47.

39 Martin EM, Clapp PW, Rebuli ME, et al. E-Cigarette use results in suppression of immune and inflammatory-response genes in nasal epithelial cells similar to cigarette smoke. Am J Physiol Lung Cell Mol Physiol 2016;311:L135-44.

40 Miyashita L, Suri R, Dearing E, et al. E-Cigarette vapour enhances pneumococcal adherence to airway epithelial cells. Eur Respir $J$ 2018;51:1701592.

41 Reidel B, Radicioni G, Clapp PW, et al. E-Cigarette use causes a unique innate immune response in the lung, involving increased neutrophilic activation and altered mucin secretion. Am J Respir Crit Care Med 2018;197:492-501.

42 Ghosh A, Coakley RC, Mascenik T, et al. Chronic e-cigarette exposure alters the human bronchial epithelial proteome. Am J Respir Crit Care Med 2018;198:67-76.
43 Zhao J, Zhang Y, Sisler JD, et al. Assessment of reactive oxygen species generated by electronic cigarettes using acellular and cellular approaches. J Hazard Mater 2018;344:549-57.

44 Marini S, Buonanno G, Stabile L, et al. Short-term effects of electronic and tobacco cigarettes on exhaled nitric oxide. Toxicol Appl Pharmacol 2014;278:9-15.

45 Palamidas A, Gennimata SA, Kaltsakas G. Acute effect of an ecigarette with and without nicotine on lung function. Tob Induc Dis 2014;12:A34

46 Schober W, Szendrei K, Matzen W, et al. Use of electronic cigarettes (e-cigarettes) impairs indoor air quality and increases FeNO levels of e-cigarette consumers. Int $\mathrm{J}$ Hyg Environ Health 2014;217:628-37.

47 Antoniewicz L, Brynedal A, Hedman L, et al. Acute effects of electronic cigarette inhalation on the vasculature and the conducting airways. Cardiovasc Toxicol 2019;19:441-50.

48 Etter J-F. Electronic cigarettes: a survey of users. BMC Public Health 2010;10:231.

49 Bullen $\mathrm{C}$, McRobbie $\mathrm{H}$, Thornley S, et al. Effect of an electronic nicotine delivery device (E cigarette) on desire to smoke and withdrawal, user preferences and nicotine delivery: randomised cross-over trial. Tob Control 2010;19:98-103.

50 Wang JB, Olgin JE, Nah G, et al. Cigarette and e-cigarette dual use and risk of cardiopulmonary symptoms in the health eHeart study. PLoS One 2018:13:e0198681.

51 Shahab L, Goniewicz ML, Blount BC, et al. Nicotine, carcinogen, and toxin exposure in long-term e-cigarette and nicotine replacement therapy users: a cross-sectional study. Ann Intern Med 2017:166:390-400. 